\title{
Accumulating Roma cultural capital: First-in-family graduates and the role of educational talent support programs in Hungary in mitigating the price of social mobility ${ }^{1}$
}

\author{
Julianna Boros ${ }^{2}$ - Péter Bogdán ${ }^{3}$ - Judit Durst ${ }^{4}$ \\ https://doi.org/10.51624/SzocSzemle.2021.3.4 \\ Manuscript received: 05 August 2021. \\ Revised manuscript received: 05 October 2021. \\ Acceptance of manuscript for publication: 18 October 2021.
}

\begin{abstract}
Based on 165 in-depth, narrative life story interviews with first generation graduates, fieldwork with educational support initiatives and auto-ethnography, this article contributes to the literature on whether and how structural educational inequality can be compensated by talent support programs and whether and how these programs can mitigate the price of education-driven upward social mobility for those Roma and nonRoma Hungarians who come from socio-economically disadvantaged families.

Upwardly mobile Roma who achieve social ascension through academic high achievement usually travel vast social distances that straddle class and ethnic context. Many of their mobility trajectories are accompanied by a set of challenges that are unique to college educated, racialized, underrepresented minorities. To overcome these challenges, and to compensate for the inequality of life chances that originate from their socially and economically disadvantaged family backgrounds and from an unequal and highly selective educational system, upwardly mobile minority students join educational support initiatives or organisations. This paper, drawing on the narratives of our research participants, argues that particular types of these initiatives or charitable foundations that deploy an ethnically targeted complex approach, can equip their beneficiaries with different types of capital. Amongst these, one of the most important is the Roma cultural capital. The newly gained capitals are necessary for the first-in-family Roma mentees to get through higher education and succeed in the labour market in the context of the specific challenges they face. These initiatives mitigate the price of social ascension the most. The paper uses a case study of Romaversitas to demonstrate its main findings.
\end{abstract}

Keywords: social mobility, price of upward mobility, Roma disadvantaged students, educational support programs, talent programs, Roma cultural capital, Romaversitas

1 The empirical material that this paper benefits from has been collected during our 3-year research project, titled Social mobility and ethnicity: Trajectories, outcomes and hidden costs of mobility, supported by the Hungarian Academy of Sciences' (NKFHI) research grant (no. K-125 497). We are indebted to Zsanna Nyírö, our research team member, for her valuable comments on the first draft of this paper. We also thank the two anonymus reviewers for their helpful comments and suggestions.

2 University of Pécs, Faculty of Humanities, Department of Community and Social Studies, email: boros.julianna@pte.hu

3 Learning Centre Foundation of Budaörs, email: bogdan.peter1979@gmail.com

4 Institute for Minority Studies, Research Centre for Social Sciences, Department of Anthropology, University College London, email: durst.judit@tk.hu 


\section{Introduction}

One of the most important tasks of education policy is the mitigation of educational inequalities through facilitating school success for students coming from various socio-cultural contexts. However, the Hungarian education system is highly inequitable and is one of the most selective in the European context (Radó 2018, OECD 2018). Mechanisms of selectivity are highly complex and include both institutional and informal processes (Radó 2018, Papp Z.-Neumann 2021). This selectivity is the general context of the Roma (educational) segregation (Radó 2018). Educational experts have long warned us, however, that policies aiming to facilitate the success of students of socio-economically disadvantaged families who perform poorly in school could increase the low effectiveness of the Hungarian education system (Havas-Liskó 2006, Halász-Lannert 2006, Forray-Pálmainé Orsós 2010, Hajdú-Kertesi-Kézdi 2014, Lannert-Németh-Szécsi 2018).

In Hungary, several formal and informal educational programs were launched in the 1990s to compensate for educational inequality and to foster the educational achievement of disadvantaged students, and in particular, of those from Roma background. The facilitators and donors of the programs that specifically targeted Roma youngsters have mostly been non-governmental organizations (NGOs). In this paper our discussion centres on two questions: 1.) How structural educational inequality can be compensated by talent support programs, that is, how these programs contributed to the upward mobility of first-in-family Roma graduates who were identified as 'gifted' students? 2.) Whether and how these programs can mitigate the price of education-driven upward social mobility? To answer these questions, we draw on the empirical materials of a 3-year wider research project on the outcomes and the hidden costs of education driven social mobility among Roma and non-Roma first-in-family university graduates in Hungary. We systematically explore the impact of those educational support programs that our study participants mentioned that they were beneficiaries of.

The paper proceeds as follows. The first section introduces the theoretical background of our research. Here we use the concept of different types of dominant and non-dominant cultural capital accumulation, the price of mobility and the minority mobility trajectory as analytical tools that we find helpful to analyse our empirical results. The second part presents the research methodology and reflects on the positionality of researchers that we believe has an impact on the lens through which we interpret our findings. The third section offers a typology of educational support programs that our study participants benefited from. The fourth section tackles the question of how talent-nurturing educational support programs affect social mobility and how, if at all, they can mitigate the price of it, using a case study for illustration. Finally, the concluding section summarizes our research findings and its implications for the civic, policy and research fields. 


\section{Theoretical framework}

\subsection{Social trajectory and different types of dominant and non-dominant cultural capitals}

If we are to make sense of social mobility from the lower or working class, three Bourdieusian concepts are of particular interest for our study. The first one is the idea of social trajectories. According to Bourdieu's explanation of individual actions, people's movements take place in social space where they live out social trajectories (Mallman 2018). Social trajectories are the series of positions successively occupied by the same agent in successive spaces (Bourdieu 1996: 258). As Mallman explains, these trajectories operate by the function of different, symbolic, cultural and economic capitals, which are not fixed properties. As lives unfold, the types and amounts of capital people possess and operationalise change over time (Bourdieu 1984). It's also important to note that capitals, among them the cultural capital, have the capacity to produce profits and to convert to material gains (Bourdieu 1986).

Conventional studies on socio-economically disadvantaged families where many of the upwardly mobile, first-generation professionals come from, describe this group with economic and cultural capital deficit (Mallman 2018, Friedman 2016). However, ethnographic studies show that there are two core forms of cultural capital at play in the lives of racialized minorities. Carter (2003, cited by Wallace 2016) speaks about dominant and non-dominant cultural capital. That is, the legitimated and alternative forms of cultural capital (Abrahams et al. 2016). She defines dominant cultural capital in keeping with Bourdieu's original definition - that is cultural knowledge, specialised skills and distinct practices (and tastes) inherited and used by privileged classes to maintain high status and reproduce power in mainstream society. Nondominant cultural capital, on the other hand, refers to the cultural resources lower status groups possess to manage their status within their local communities. (Carter 2003). Those who have access to dominant cultural capital in home and social context such as in school environment, experience cumulative advantage in school (Lareau 2011). It is because formal education inculcates dominant middle-class cultures and only values dominant (white middle class) cultural capital. These are the kinds of cultural competencies that are hard simply to acquire (Bourdieu 1984, Friedman 2016). Therefore, many working-class born, first-in-family graduates feel injustice and uneven competition in workplaces where white middle classes are dominant (Friedman 2016). As Skeggs (1997: 129) puts it, "the inability to trade one's [nondominant] cultural capital because it has only limited value or is not recognised in the places where value can be accrued is a substantial disadvantage to and sign of being born working-class."

In the same line of thinking, Yosso (2005) suggests, by exploring the educational success of People of Colour (as she calls the visible minority groups, often stigmatised by race), that they are not deficient of cultural capital - they just do not possess the 
dominant type of it. Many of these socially marginalised groups rather accrue an "array of cultural knowledge, skills, abilities, and contacts that often go unrecognised" (Yosso 2005: 69). Yosso calls this (by the dominant majority) unrecognised cultural capital 'the community cultural wealth.' Drawing on Yosso's Critical Race Theory approach, Óhidy (2016) speaks about Roma community cultural capital.

Following the same logic, Wallace (2016) suggests the concept of 'Black cultural capital' (in a localised, gendered and generational dimension) as a response to the historically marginalised position of 'Blacks' in British society. According to Wallace, Black cultural capital is "a set of resources both working class and middle-class Black Caribbean youth deploy to make meaning of Black identities, forge networks of belonging and counter their marginal status, given Britain's racialized power relations" (Wallace 2016: 41). Wallace (2018) argues that sociological research too often renders cultural capital synonymous with whiteness.

Here we use the term 'White' and 'Black' as an analytical concept, borrowing this approach from Whiteness scholars. For Whiteness scholars, the term 'Whiteness' (and its relational counterpart, 'Blackness') and 'white' ('black') is not to describe a discrete entity (for example, skin colour alone) but to signify a constellation of social processes of domination practices and race privilege (DiAngelo 2011). In this sense, Whiteness as an analytical notion, refers to the specific dimensions of racism that serve to elevate White people over people of colour. Although Whiteness studies were born in the U.S. context, their structural approach makes the concept of Whiteness a heuristic analytical tool in the context of Romany Studies too (Kóczé 2020).

\subsection{The price of upward mobility and the minority mobility trajectory}

There is a research tradition starting with Sorokin's (1959) insight that high upward mobility and ensuing rapid change in social contexts can lead to identity-related problems and mental disorders for the upwardly mobile.

A growing scholarship calls it either 'the price of the ticket' (Friedman 2014); the 'emotional costs' (Reay 2005) or the psychological strain of social ascension. Bourdieu even speaks of a 'habitus clivé' in his autobiography (Bourdieu 2008, cited by Friedman 2014), indicating a 'dislocated habitus' or a 'divided loyalty' between one's background of origin and attained class.

Naudet (2018) proposes that this emotional cost stems from a tension that has two sides. One is sociological, the other is a moral aspect. The sociological aspect is related to the different experience for the upwardly mobile of two paths of socialization: the primary one in the field of the family of origin and the secondary one from school (and work) context. The tension arises if these two paths or fields function according to different, or even contradictory principles. Skeggs (1997), in a similar way, speaks about the 'hidden injuries of class mobility.' From her own experience, she explains that for many upwardly mobile people, strained family relations and a divided sense of self accompany the benefits of 'rising above one's station.' 
The other side of the tension is its moral aspect (Naudet 2018). For many of those who experience social mobility there is a choice whether they stay committed and keep solidarity with their background of origin, despite their acculturation to the dominant middle-class norms and values through their secondary socialisation in schools. This choice, especially in the case of those belonging to discriminated and stigmatised racial groups, is a moral one and it demands taking sides. And even in the common cases when one tries to stay committed to his background of origin one can be blamed that s/he betrayed her/his class by 'rising above her/his station' (in the case of Roma by "becoming Hungarian", "elmagyarosodott").

The common experience of discrimination along with a strong feeling of solidarity towards the group of origin seem to be common in the narratives of upwardly mobile members of racialized minorities across different countries (Naudet 2018). To cope with this distinctive problem, upwardly mobile minority middle classes develop the repertoire of a so called 'minority culture of mobility' (Neckerman et al. 1999), or as we prefer to call it in the case of our Roma first-in-family respondents, the 'minority mobility trajectory' (Durst-Bereményi 2021). A part of this repertoire is the ethos of mobility to 'give back' to one's community of origin by working in a segmented part of the labour market where one deals with 'Roma Issues'. ${ }^{5}$

\subsection{Mentoring programs and educational mobility}

Widening participation in higher education for marginalised groups has been considered by policy makers as a necessary development in the globalizing world to break the cycle of their transgenerational social exclusion, especially in the context of the 'global knowledge economy' (Morley 2014). Mentoring programmes are seen as successful measures in helping socio-economically disadvantaged pupils and students to achieve better results in school and to create more equal opportunities in education (DuBois et al. 2011, Óhidy et al. 2020). Mentoring can provide huge benefits in socio-emotional, cognitive and identity development of the mentees, and mentors can become important door openers for disadvantaged children (Óhidy et al. 2020). They may also be able to challenge negative views that the mentees may hold of themselves (DuBois et al. 2011). Roma academics and activists argue however, that initiatives facilitating wider access to "merit-based education aiming at effective social inclusion of Roma must be combined with politics of recognition that encourages ethnic pride, belonging and identity" (Mirga-Redzepi 2020: 53).

The number of educational support programs for Roma and/or socio-economically disadvantaged students ${ }^{6}$ has increased in Hungary since the second half of the 2000s. It means that it has been mainly our younger interviewees that participated in such initiatives. As Forray (2017) highlights, studies on the impact of these programs are rare

5 In our definition such jobs are related to the Roma issues which aim at improving the situation of Roma people living in poverty and support the protection of their interests (see also Váradi 2015).

6 For a list of educational support programmes at all educational levels for disadvantaged and Roma students see Boros 2019: 48-52. 
(apart from a few exceptions see e.g. Dezső 2013, Arnold et al. 2011). Targeted research on the educational support programs mainly concentrated on the effect of the Roma Student Colleges Network's initiatives on their upwardly mobile Roma mentees' social trajectory. Forray (2017) delineates the history and missions of the Students Special Colleges Network, including the Romaversitas (created by the Soros Foundation in 1993) and the Christian Roma College Network (founded by the Hungarian churches in 2011). She asserts that these organisations originally aimed preparation for important intellectual and public roles at the most talented students. She also draws attention to some common features of these support programs. Firstly, they were aimed at helping their students "appropriate the cultural values and behaviours of the middle class" (by taking them to visit museums, concerts and the theatre). Secondly, apart from accumulating this dominant ['white'] cultural capital for their students, they aimed at contributing to the personal development of their mentees - according to their founder's or donor's ideology/worldview (Forray 2017). This explains why in their narratives some of our interviewees mentioned that after a short discussion one can easily find out 'which box you come from', that is, in which support program one got socialised.

Analysing the personal network of one of these Roma college students, LukácsDávid (2018, along with Stanton-Salazar 2004, Bereményi-Carrasco 2017, to name a few,) found that social capital accumulation through these colleges partly explains the successful Roma higher education path (see also Óhidy 2016).

Beyond social capital, Varga et al. (2020) demonstrates the role of these college mentoring programs in accruing and accumulating psychological capital (Luthans et al. 2010), that is, developing positive self-image, self-efficacy, hope and resilience. This positive psychological capital has been proven to significantly increase individual and organizational performances (Luthans et al. 2010).

Bereményi and Giros-Calpe (2021), however, draw attention to the limits of mentoring programs in respect that they are not able to tackle systematic injustice in educational systems. They insightfully demonstrate that in the case study of a Spanish intra-ethnic Roma mentoring project, the mentoring's primary object is 'people to be developed' and not the structure that is to do the developing.

In the following discussion section, we will investigate the impact of the particular support programs and Non-Governmental Organisations (NGOs) that were frequently mentioned in the narratives of our research participants as those that help them regarding their educational mobility. But before that we need to introduce our research methods.

\section{Research methodology and researchers' positionality}

This paper bases its argument on the empirical findings of a larger, 3-year research project that explores different education-driven social mobility trajectories, their outcomes and their consequences on the life and subjective well-being of 165, first- 
in-family Roma and non-Roma graduates in Hungary. In this project we conducted semi-structured, narrative in-depth, life story interviews with individuals whose parents did not have a university degree and many of whom came from socioeconomically disadvantaged family backgrounds. All interviews were recorded, transcribed, and de-identified to ensure anonymity, and coded with Atlas.ti program.

Participants of the project were recruited through snowball sampling. We used different channels - our personal networks, the networks of generic Roma institutions, and Facebook advertisements - to find our interviewees to decrease sampling bias. As the research team consisted of both Roma and non-Roma researchers, our personal networks for recruiting the participants of our study were quite heterogeneous. We considered our interviewees Roma according to their self-identification.

Our research team was concerned with 'epistemic justice' (Morley 2020): Roma researchers were in the position of knowledge producers rather than simply the objects of inquiry. We, the first two (Roma) authors of this paper, were inspired by Ingram and Abrahams (2016) work on how a divided habitus can lead to reconciliation by integrating middle class and working-class worlds. Their work on habitus interruption and on the reflexivity that it brings with itself, resonated with our upward mobility journey through which we have navigated between the two social spaces we occupy: our Roma working-class family background and the middle-class position we attained through our further studying and through our belonging to academia. We believe that our self-reflection on what support programs have meant to us throughout our education-driven mobility journey, will shed light on the role of these initiatives both in facilitating upward mobility by accruing dominant (white middle class) and non-dominant (Roma) cultural capital; and in mitigating the cost of our traveling huge social distances by healing the "hidden injuries of changing class" (Skeggs 1997) and by re-casting our Roma identity. ${ }^{7}$

Julia's parents are Romungros, that is Hungarian Gypsies. They lived in the Gypsy settlement on the outskirts of a small village in South Hungary. They managed to move out from the Gypsy settlement to the Hungarian neighbourhood, among the non-Gypsies when she was young. Her mother has 6 years of schooling, her father has 8 . Both had worked as semi-skilled labourers their whole lives.

She always felt different to her cousins, though in primary school she was an average pupil, in secondary school she started to excel. This was because she had a very supportive teacher who believed in her and thought she had more academic potential than to end up in a vocational school (where most of her Roma schoolmates were advised to go). Her parents were proud of her and they wanted her to be a lawyer, although they did not have a clue what and where she needed to go to study to become a lawyer.

7 The third author of this paper comes from a very different, white middle class background with a 'migrating' habitus (Thatcher- Halvorsrud 2016). Although she has no personal experience of the effect of educational support programs on mobility, her own social coordinates inevitably impacted the research that this paper benefits from. We believe, along with a few other scholars (Németh 2015, Friedman-Laurison 2020, Kovács-Gárdos-Vajda 2020, Máté 2021), that it is necessary to reflect on our own positionality as it certainly has affected not only how comfortable interviewees felt in sharing their personal experiences of the sometimes-painful road to mobility but also, how we interpreted our findings. 
Although she was recruited by a Roma talent nurturing secondary school, the Ghandi Gymnasium, her parents did not let her go there. They said she was clever enough to pull through any (majority, non-Roma) grammar school. She did indeed get into a strong secondary school in the nearby town with the help of a foundation (Amrita) that supported the secondary level education of children from socio-economically disadvantaged family backgrounds. She made strong and lifelong friendships with the other Roma children who were also beneficiaries of Amrita's initiatives.

Since then, she has enjoyed the support of many pro-Roma charitable initiatives. During her grammar school years, she managed to live in the capital city of South Hungary in a Roma talent nurturing dormitory. Here she learnt the most about her Gypsyness, and her minority identity got stronger. Then she met the colleagues of the Kurt Lewin Foundation (KLF) who recruited Roma grammar school students of working-class backgrounds to enrol in their free university entry preparation course. With their help she managed to be accepted onto a social policy course in one of the top universities in the capital, Budapest. Now she believes she did not choose this field of study because that was what she wanted to but because that was what she had the opportunity to do. Later, she became a fellow of the Romaversitas Invisible College. Here her Roma intellectual identity became strongly developed. She felt she was a member of a like-minded Roma community where studying is a universal value for everyone. This was a totally new experience compared to the one she had in her background Roma community.

Péter is from a rural settlement in Northeast Hungary. Although his mother had finished only elementary school, she instilled in him a love for reading from an early age. During his elementary and secondary school years and even at university, the role of non-Roma teachers and intellectuals was decisive in his personal and intellectual development. All his non-Roma mentors of his formative years agreed that he needs to be supported not only because of his socially disadvantaged family background but also because it is important for the whole society that they nurture another Roma intellectual (to add to the very few).

His primary school education was financed by his mother, however, his secondary level studies were supported by different scholarship programs (among others the Soros Foundation) and various Roma NGOs. During his university years he drifted to the world of Roma public life, and he received immense support from them too. After his first year at university, he became a fellow of the Romaversitas. From then on, although he still enjoyed the support of some non-Roma professionals, his life was determined by prominent Roma intellectuals. They are the ones who have shaped him into the bi-cultural Roma intellectual he is today, one who can perform the 'bridge role' between Roma and non-Roma.

These different class backgrounds of the 3 researchers of this paper played an important role in our collaboration of interpreting our data. In the next section we explore this interpretation. 


\section{Discussion and Results}

\subsection{The history of educational support programs for disadvantaged students}

While there is no doubt that higher education expansion can increase social mobility by providing access to formerly excluded groups such as the Roma in Hungary, much research indicates how inequalities are preserved within and besides an expanding tertiary education in the case of Roma graduates in Eastern and Southern Europe where most of the Roma population are concentrated (Garaz-Torotcoi 2017). One indicator of the well documented historical educational gap between Roma and majority students is the discrepancy between the ratio of tertiary graduates among majority and Roma students. A 2011 UNDP Roma survey, one of the very few datasets providing multi-country statistical data on the educational attainment of Roma in Eastern and Southern Europe, showed that only 1 per cent of those identified as Roma in the observed countries have postsecondary education (Brüggeman 2014). The situation is similarly bleak in Hungary. According to the latest Census in 2011, 23 percent of the Roma population did not even complete primary school. 13 percent of them graduated from secondary level vocational school where they do not receive A-level certificates, while only 5 percent of them completed high school with A-level credentials (matriculation). Only 1 percent of them graduated in higher education (Bernát 2014).

In Hungary, several formal and informal educational support programs and initiatives were launched in the 1990s to compensate for these educational inequalities of disadvantaged students, especially of those from a Roma background. These civic organizations have been financed to implement programs by private donors (for instance Soros Foundation). The main advocacy actors of the programs have been geographically diverse, and have emerged from the civil sector, religious organizations, and minority municipal self-governments. This is due to the fact that arising difficulties have been addressed at a local level following the principle of subsidiarity, given a lack of governmental financial support. Most of the programs started out as pilots or models for further initiatives. However, a common feature is that all support programs have attempted to compensate for the lack of opportunities for children of socio-economically disadvantaged family backgrounds, as schools did not fulfil their institutional function to reduce social inequalities.

Nonetheless, it became clear early on that the supplementary programs outside the field of formal education were not suitable to address the systemic problems - that have been present ever since (in formal education), which determine the future social mobility prospects (more precisely, the lack thereof) of disadvantaged students, the majority of which are Roma.

It became apparent in the mid-1990s that the educational underachievement of Roma students has increased, furthering negative associations amongst Roma 
students of studying and school due to their disadvantages originating in their socio-economic status on the one hand and also due to the systemic chaos of primary education (institutionalized segregation and direct and subtle educational selection mechanisms (Radó 2018). This has had a profound impact on their career orientation and study aspirations.

Reflecting on these systemic problems, initiatives emerged in the 1990s to help foster the educational success of Roma students. Among others, the Gandhi High School and College was the first Romani high school established in 1994 by various experts (Dezső 2011). Several scholarship programs were launched that granted financial support for children based on school performance and ethnic origin. Scholarships were initially financed by the Soros Foundation and were later complemented by various governmental bodies and national-level organizations through governmental support programs (Havas 2007, Messing-Molnár 2008). A similar pattern emerged through these initiatives. Students had to apply for the scholarship, so in terms of efficiency, the system was highly selective. The regional coverage of scholarship opportunities has not been extensive and as a result, it has not reached out to all those in need of support. The availability of information depended primarily on the networks of students and their families, on their cultural and social capital. Whether the students were eligible to apply was predicated on the supportive attitude and interests regarding the scholarship in the social environment around the students (mainly teachers) (Havas 2007, Messing-Molnár 2008, FehérváriVarga 2018). This thesis is supported by the findings of our research.

Apart from these support programs, several NGOs/civil society actors were set to help Roma students to finish elementary school and advance their studies in secondary schools (often through career guidance activities). Their attempts have facilitated a growing number of Roma students in finishing their elementary studies (Havas-Kemény-Liskó 2002; Kemény-Janky- Lengyel 2004, Hajdú-Kertesi-Kézdi 2014, Varga 2018). Several programs, later known as extracurricular, informal schools or afterschool facilities ('tanoda') have been organized for primary school students to compensate for their disadvantages.

Several outstanding innovative initiatives have been launched by teachers intending to develop the educational prospects of Roma students in the Southern Hungarian region (Baranya county) following regime changes. Apart from the set-up of the Ghandi High School, and the Amrita OBK Association's career guidance service, the Collegium Martineum, a dormitory was established focussing on special skill development and identity building programs for Roma students. According to experts and those involved, these emerging initiatives have been launched mostly in a selforganizing way for various reasons. The availability of new financial resources (e.g. one of the key Roma programs by the Soros Foundation) has enabled the conception and implementation of various educational development initiatives, advanced studies for teachers, and the development of student-teacher patronage scholarship systems. 


\subsection{Prevalence of ethnic/minority or social dimensions in the programs}

The ongoing socio-economic changes have brought forward new challenges to the education policy of the 1990s. The policy interventions that had the objective of improving the prospects of Roma students, have been ambiguous and equivocal. Most challenges have emerged from the fact that the government could not firmly decide whether the main perspective in approaching the Roma population was human, minority or social rights, or employment policy (ÁSZ 2008).

In the 1980s and 1990s, Hungarian education policy relied primarily on ethnic policy perspectives. The scholarship program for Roma students, financed formerly by the Public Foundation for Hungarian Roma, and later by the Office for National and Ethnic Minorities, the first Romani high school, Gandhi High School and the first Roma advanced college, Romaversitas have been organized along ethnic lines. The central target group of these types of initiatives have been students of Roma origins.

The parallel processes of regime changes and the popular validation of minority rights have significantly impacted education policy. Ethnic Romani students, as with other minorities in Hungary, have gained minority rights. Ethnic and minority education has started to materialize and the preparation for education in Romani languages (Boyash and Lovari) have been legally enabled. It became enshrined in the law in 2013 through Act 16/2013 (III.1. EMMI) which encompasses directives regarding ethnic school education (Orsós 2015, Boros 2019).

Given the social and economic processes that have taken place in the 2000s, public education policies fostering school success amongst Roma pupils have gradually incorporated a social aspect. The provision of support for disadvantaged groups, including Roma students, has become a focal point of these policies. In this period, target groups and objectives have shifted from ethnic considerations to social aspects by providing support for socially disadvantaged groups. Respectively, programs offering targeted support for Roma students have been side-lined, Roma scholarship programs ceased to exist. Instead, scholarship programs have been established for marginalized groups, such as the 'Utravaló' (On the Road Scholarship program). The underlying perspectives behind this move do not indicate that school underperformance is an ethnic issue; instead, they demonstrate that the issue is mostly defined by socio-economic status (Papp Z. 2011). Integrational and skills-based norms have been introduced along this new central objective: social and educational integration in education policy and primary education. "Public education has drawn a strict line in 2002 by introducing IPR [Integrated Pedagogical System] for socially disadvantaged students, combined with multicultural elements that indicate that this move is not colourblind in terms of cultural differences" (Varga 2016: 73). Despite the paradigm change, educational actors that consider disadvantaged students as a pseudonym or synonym for Roma students have still been and remain the majority. 


\subsection{Typology of the educational support programs}

It is not an easy task to create a typology for the programs that have been initiated in the last three decades to support Hungarian Roma and disadvantaged students on their educational trajectory. This is not the focus of this paper, either. However, we find it helpful to systematize the initiatives that our interviewees mentioned in their narratives as a facilitating factor in their upward mobility. Based on this systematic analysis, we differentiate between seven types of support programs.

\section{The 'intellectual family model' (extracurricular schools)}

Extracurricular, informal school-like institutions have been offering services to students in primary and secondary education since the mid-1990s. In terms of target groups, beneficiaries mostly included disadvantaged Roma students. In the early period, programs were launched by civil organizations specifically tailored to local needs, seeking to improve school achievement, decrease disadvantages and offer leisure-time, cultural activities to compensate and accrue mainstream cultural capital that their mentees did not bring from home. Nowadays, these programs support disadvantaged and Roma students' school performance at both elementary and secondary levels. The following initiatives of this category were listed in the narratives of our study participants: Amrita OBKAssociation's program, Józsefvárosi extracurricular school, and Bhim Rao Association's program.

\section{Patronage/mentoring model}

Support programs in this category combine financial support (scholarships) with personal mentoring, and specific school-related support. The patronage/mentoring model compensates for family disadvantages through the presence of an intellectual expert, which is the main strength of the model. The patron/mentor supports Roma students with their knowledge, skills, empathy and help in understanding and achieving better school results; they also help solve any related school or personal life problems. The effectiveness of the model is unquestionable as it appears that the patron/mentor is a determining factor in career guidance and acts as a mediator and translator in the life of the student. The mentor, who is often a teacher, is personally committed or devoted to his/her disadvantaged student mentees. For their services, the patron/mentor receives financial remuneration, while the student is awarded a scholarship. The model creates opportunities that serve as a bridge between the family socialization sphere and the institutional life at school. The following programs can be categorized in this model: the scholarship program of the Soros Foundation, the 'Útravaló' scholarship program and the Roma Mentor Project. All of them were mentioned in the discourse of our research participants on the facilitating factors of their upward mobility. 


\section{Scholarship model}

Schools with the objective of supporting Roma students financially may be categorized as part of the scholarship model. There are mostly two types of scholarships: those that may be used by beneficiaries optionally, and targeted scholarships that finance education fees. Programs are offered by the National Bank of Hungary, by the Ministry of Education and MACIKA. Good academic performance, ethnic identity and being in a socially disadvantaged position are usually prerequisites of the scholarship. All our interviewees who received any of these scholarships during their school careers took part in other, more complex support programs too, for example at the Romaversitas. However, many of them emphasized the symbolic value of scholarship. It was the first time for many members of the Roma community that studying was financially valued.

\section{Intellectual community, professional mentoring and social networking model}

Colleges of advanced studies, designed for students in tertiary education have become especially relevant in the 2010s. On the one hand, advanced colleges offer professional academic assistance, and on the other hand, they play a significant role in providing participating students with a family-like, mostly ethnic community. Members of the community become intellectuals through the internalization of the community's (the advanced college's) values. Social responsibility and strengthening minority identity are concomitant with academic expectations, and in supporting the Roma population, the community's values and social solidarity, there is an indirect implication that the student will 'give back to the community'. The following organizations were mentioned by our interviewees from this category: Romaversitas 'Invisible College of Advanced Studies', Wlislocki Henrik College of Advanced Studies, Roma Advanced Studies of Gödöllő, as well as the Christian Roma College Network's institutions. The majority of our study's Roma participants were members of one of these Colleges and mentioned them as one of the most influential factors in mitigating the price of their upward mobility.

\section{Talent nurturing model}

Talent development programs that primarily select beneficiaries based on their school performance or talent in any kind of art or in any academic subject, in elementary and secondary school have been prevalent in all observed periods. The programs support students who are motivated, and whose previous school records indicate that they are hardworking, diligent, or otherwise considered exceptional among their peers with similar socio-cultural backgrounds. Some talent development programs are specifically aimed at making financial and personal provision, for example, by providing a room in a student residence. The Collegium Martineum Gypsy Talent Development Residence (1996-2008) and the János Arany Talent Development Program (2000-) are examples of this type. Others like the New Start Foundation 
(Új Start Alapítvány) Roma talent program offer monthly scholarship, identity building, mentoring and summer camps - all of which contribute to facilitating social mobility by accumulating cultural and social capital and creating community among like-minded talented Roma students from socio-economically disadvantaged family backgrounds.

\section{Second chance school's model}

Second chance secondary school programs improve the educational progress opportunities and elementary-secondary graduation prospects of Roma students within the boundaries of formal education. The central emphasis of the model is placed on minority identity and compensation for disadvantages stemming from the low socio-cultural background of students. The programs may also be perceived as a second chance or a 'new opportunity' as without these, students who dropped out early from formal education would most likely reproduce generational deprivation and would not be able to break out of cyclical disadvantages without a profession. These initiatives stem from the realization that most educational support programs do not reach those who are most in need. Our research confirms this thesis: among our 165 study participants there were none who came from a marginalized and ethnically segregated small village rural neighbourhood, or from a segregated school. From this category our first-in-family graduates only mentioned the Dr. Ambedkar Secondary School as a facilitator of their education-driven upward mobility.

\section{University entry preparation programs}

Various civil organizations and higher education institutions have implemented university entry preparation programs since the 1990s. One third of our middleaged research participants had benefited from a university preparation program facilitated by the Kurt Lewin Foundation (KLF). Many of them mentioned in their narratives that without the support of the KLF, they would have never been admitted into higher education, partly because of their feeling of the lack of self-efficacy (see Ligeti 2001, Nyírő-Durst 2018). KLF's program for secondary school students from poor family backgrounds operated from 1995 to 2007. The aim of this initiative was to promote the social integration of disadvantaged students, by facilitating their access to higher education (HE) and supporting them psychologically and professionally throughout their HE trajectory.

Another formative, educational support program that came up in the narratives of our research participants was the Roma Graduate Preparation Program (formerly known as the Roma Access Program at the Central European University (CEU), that was initially supported by the Open Society Foundation (OSI). Few of our interviewees recounted it as one of the most influential support programs on their educational mobility path. As Ella (35, a project manager in an international foundation) put it: "It was the place for my intellectual awakening. It gave me community; I found my 
best mate here. Together with Romver, it hugely strengthened my identity. At last, I have found my place in the world as a Roma intellectual" (see also Kende 2007).

However, there were a few current students of this program who shed light on the dilemma that many of our respondents articulated who were former beneficiaries of Roma educational support initiatives/organisations but did not want to work in Roma oriented professions (the so called 'Roma issues' (Nyírő-Durst 2018). Eszter (24, studying social sciences) summarised this feeling eloquently:

"There is a dilemma. It's good that I'm in this program. It helps me immensely in getting over my feeling of inferiority, it equips me with the cultural capital that I did not bring from home, from my primary school educated parents. But at the same time, it made me develop a burdensome feeling of responsibility. I feel that I am one of the selected few who had access to the knowledge and skills that could be channelled towards helping the situation of the Roma. And it feels bad that I feel pressure that I always need to deal with Roma [Issues] whether I want to or not...I became a bit alienated in this program. For me this academic context is too dry, too abstract. I'd rather go closer to real communities, at least to an activist space where the struggle against oppression is more practical. I think I would feel even more sceptical if the leader of this program was a white guy. It's good that the director is a Roma woman, coming from a similar, poor background of origin than many of us, participants."

\subsection{How talent-nurturing support programs affect social mobility and mitigate the price of it}

Our research on the different trajectories and outcomes of education driven social mobility shows that support programs played a significant role in the upward mobility of first-generation Roma professionals. As one of our Roma interviewees reflected on his educational journey, he said smilingly that he considers himself partly the "product of the support programs." Although this statement cannot be generalized for the first-in-family Roma graduate population in Hungary, given though our sample is numerous for a qualitative study, it is not representative of the whole group. Also, one of the biggest limitations of our study like many of this kind is that we could only reach a very few (5) of those first-in-family Roma graduates who fully assimilated into mainstream society and would not want to participate in any research. These assimilated first-generation intellectuals typically avoid ethnically oriented or affirmative support programs (Pantea 2015).

However, this finding of our purposive sample of upwardly mobile Roma (and non-Roma) participants who completed tertiary level education is in line with the results of previous studies about Roma students in higher education in Hungary (Varga 2018, Forray 2015, Varga et al. 2020, Mirga-Redzepi 2020). Namely, that the vast majority, 83 percent of our Roma interviewees took part in one (or more) 
educational support programs at different stages of their mobility trajectories. On the contrary, these programs did not have a significant role in the upward mobility of our majority, non-Roma respondents, as only 13 percent of them reported that they had been a beneficiary of any of these initiatives.

One of the main findings of our research project on the psychic or emotional price of upward mobility is that those interviewees who belong to the Roma minority are more likely to experience 'dislocated habitus' or 'habitus clivé' than the majority of the participants of our study (Nyírő 2021, Nyírő-Durst 2021, this volume). That is, belonging to a racialized, stigmatised and discriminated minority group has a significant influence on the subjective experience of upward mobility. This is because upwardly mobile, racialized minority people, such as the Roma in Hungary face a distinctive problem. Unlike their 'white' majority counterparts, who are taught to think of themselves as individuals rather than as part of a racially socialised group (see also DiAngelo 2011 for white Americans), Roma graduates, many of whom rose from poverty, carry the psychic burden of race in a society where institutional racism permeates in many social fields, especially in education and in the labour market context (Nyírő-Durst 2021, this volume). As one of our interviewees puts it:

"Whether I want it or not, they consider me a Roma woman, a Roma expert. I would like to be just another human being, but I know that during these times [when the Roma still experience social disadvantage and discrimination], I cannot afford to do that. This is a big burden on my shoulders." (Anita, 40, social scientist and a voluntary youth worker).

This type of burden originates from the unjust and unequal power relations and distribution of social and political resources between 'white', majority Hungarians and the Roma. Many of our Roma participants reflect on their emotional (and practical) fight against the embodied message of the majority society about 'white superiority'. Some of their narratives speak about how one cannot avoid internalising this message from an early age, from a primary school context where Roma students were underrepresented.

The other type of this psychological burden of race for Roma first generation graduates stems from the fact that many of them feel that the dominant society assigns different (inferior) roles to their stigmatised community of origin. This assignment already starts at elementary school level. As one of our respondents reflected on his early age negative school experience:

"By year 7, I gave up studying. Although I had the nicest handwriting in my class, my Hungarian literature teacher never gave me a better grade than 2 , or rarely 
a $3 .^{8}$ For us, [darker skinned] Gypsy kids, we had to perform three-four times better to get the same grade as the [white] Hungarian children. The idea that they could support Gypsy students to carry on studying at secondary level, did not even come up in our teachers' minds. No one from my Gypsy settlement had ever studied further, before me." (Jenő, 42, teacher).

Because of this unjust inequality and oppression, many who made it against the odds to succeed to a higher educational level, develop a collective responsibility toward their oppressed community.

"8 years after finishing primary school, working in a factory and then being unemployed, I came across the Amrita Association and then I got connected with the founder team of the Gandhi Secondary School. They helped me enrol in the Workers' High School and I finished with a maturity (A-level) certificate. During my high school studies, I even won a competition on the subject of Hungarian language. Me, the Gypsy kid, that the teacher failed in primary school. And these supporting teachers at the Gandhi made me believe that I should study further. They made me realise that I can speak very good Boyash - which was a given for me. They taught me that because my parents cannot read or write but I'll probably have a university degree, I'll have long range mobility, and this is a huge achievement. They made me realise that I am the first with an A-level certificate in the whole Gypsy settlement and with my sister the first-in-family graduate. That was the first time I realised what an outrage it is against my Gypsy community that they are discriminated against in the education system, and they do not have access to further study, even at secondary level. This was a turning point in my life. This inclusive, supportive social environment, the pedagogists team in Baranya who welcomed and fostered the desire of the Gypsy kids to further study was the force behind my career path. I soon realised that if we want systematic change in education, that is, for our Gypsy children to be treated like equals in schools, we need to enter political life. Which meant, in my case, that as the first secondary school graduate from the Gypsy settlement, I founded the first local Roma government in my village, with the help of my sociologist friends. I called an assembly in the Gypsy settlement and told them, if I win, I will not distribute donations or food parcels, I will not organise Gypsy balls, but I will launch a further learning program." (Lali, 38, founder-director of a second chance secondary school).

This excerpt strikingly summarises the distinctive problem that upwardly mobile, racialized minorities have to face during their mobility journey (Neckerman

8 The best grade in the Hungarian schools is 5 , and the worst is 1 . 
et al. 1999), unlike their non-racialized, white counterparts. Namely, it shows the persistent salience of discrimination in not only educational settings but in everyday life, along with the importance of interclass solidarity with co-ethnic members of one's community of origin, with those (mainly relatives) who are 'left behind'. Given this distinctive problem of upwardly mobile Roma professionals, the educational support programs that proved to be the most influential, according to the narratives of our Roma study participants, are the ones that offer ethnically targeted and complex programs to foster education-driven upward mobility for the Roma. Through their identity building programmes they managed to convert non-dominant cultural capitals into legitimised, valuable ones - in the case of Lali, previously taken for granted attributes of his Romaness such as his fluency in the Beyash language was converted into a valuable cultural asset. Other respondents even managed to convert their non-dominant cultural capital, their fluent speaking of Romani language into a profitable dominant cultural capital, thanks to one of the educational support initiatives, the establishment of the Romologia department in a university in South Hungary.

"I cannot tell you how I felt, the professor came to visit me in the Café where I worked during my BA studies and asked me to teach the Romani language at her new Romologia department. A famous professor, can you imagine? Later she convinced me to pass the advanced exam in Romani language, I did as it was useful to get my BA degree in social policy." (Leila, 46, assistant professor).

One of the ethnically targeted, complex educational support programs was/is offered by the Romaversitas Foundation - an 'invisible, advanced student college' that came up in many of our first-in-family Roma graduate narratives as one of the most significant protective and facilitator agents of their mobility journey. Romaversitas was the first comprehensive support and training program for talented Roma youngsters in higher education in Hungary. Established in 1996, for the past more than twenty years Romaversitas (Romver) has supported over 300 Roma students throughout their academic studies, to enable them to successfully graduate and become highly skilled professionals in their chosen field. ${ }^{9}$

Our study participants emphasized that Romver did not just help them overcome their constant financial difficulties (by giving them a monthly stipend) and the structural barriers that underrepresented minority students face in a higher education environment (by empowering them with navigational capital ${ }^{10}$ in the circumstances of racial discrimination). They also provided them a place to meet with like-minded Roma peers, creating close friendship and dense ethnic networks and through this, a feeling of belonging and an emotional shelter (Lukács - Dávid

9 https://romaversitas.hu/about-us/

10 According to Yosso (2005), navigational capital refers to skills of maneuvering through social institutions. 
2018, Nyírő-Durst 2018). Through this support, they contributed to the mitigation of the price of their upward mobility, by reducing the psychological and emotional cost of changing class.

"My time at Romver was good and empowering. What did I get from that community? They provided me with a monthly scholarship which helped my financial situation significantly. I sent half of it home to support my mother. This scholarship had a symbolic value, too. It gave me the message that the effort one puts in studying is recognised and valued. My time at Romver also helped me overcome my identity crisis. They made me realise that being Roma can be a source of pride, not shame. I was equipped with encouragement, a sense of self-worth, solidarity, and self-belief. That is, everything that makes somebody a human, enables one to feel good in this world. Thanks to that period, I think I will never feel bad about myself anymore. There has been an enlightening in the Roma [professional] circle, a change in what it means to be Roma. There is a common belief now that it's not only the non-Roma's [Hungarian] culture that has value but the Roma, too." (Lajos, 41, social researcher).

This excerpt sheds light on one of the most important contributions of Romver (and other identity building support programs) to mitigate the price of the upward mobility of our respondents. Namely, that their complex educational program managed to accrue Roma cultural capital: a set of resources both working class and middle-class Roma youth can deploy to make meaning of their Roma identities, forge networks of belonging and counter their marginal status in Hungarian society.

For many of our interviewees, this easiness of who they are after they have changed so much during their social mobility trajectory, was the result of an identity re-construction or re-casting (Mirga-Redzepi 2020) process. This process was facilitated through their like-minded peer group and importantly by the Roma support organisations initiatives, and other mobility aiding Roma grassroots associations. Jola's reply to our question on what it means for her to be Roma, is a testimony of this reconstruction process:

"In our region, 'Gypsy' is one who queues in front of the post office [waiting for her child benefit and other social grants], who hangs around at the pub, who sweeps on the street in his phosphorescent yellow west [the uniform for public workers], and who is black. So, if I say in my neighbourhood that I am a Gypsy, then people associate me with these images, and they are confused. In olden times my Romaness to me was something to be ashamed of. But not anymore! Absolutely not. Nowadays, I have a positive sense of self-esteem, and I was happy when my daughter kept her family name even after her getting married to a nonRoma man to show the world what one can achieve in life if one is Gypsy and wants to study." (Jola, 45, social worker and teacher). 
Romaversitas has an altered mission nowadays. It was part of a move to adapt to the changing social and public education policy environment and to the needs of their Roma mentees. Among the Romaversitas Foundation's general objectives when it was founded, policy advocacy, political responsibility and integration into the Roma civil rights movement was strongly emphasized. From the very beginning, “one of Romaversitas' most pressing dilemmas has been around its selfidentification. Is it a development partner in a civil rights movement that produces proud and relentless youngsters, who represent Roma people's interests upon return to their communities? Or do the participating young Roma people simply become the best at what they do, earn professional recognition and strengthen the notion that Gypsies are just the same at what they do as anyone else?" (Expert interview in Boros 2019). When the first monitoring report of the Romaversitas was published, the Foundation considered the development of Roma intellectuals and professionals as one of its main contributions to the mobility prospects of Roma students, instead of public, political advocacy. This is especially peculiar, considering that according to the Christian Roma College Network's 2011 founding document, the network's declared goal is different, to reinforce social commitment among supported students: "A fundamental objective of the college of advanced studies is to contribute to public social responsibility through the formulation of socially committed Roma intellectuals who proactively facilitate open social dialogues, combining professional/academic excellence with social sensitivity" (KRSZH Founding Document 2011).

Today the vision of Romaversitas is a strong Romani intelligentsia that is capable of asserting the interests of Roma communities and creating narratives for Roma People. "Our mission is to help young Romani students acquire academic degrees, and strengthen their skills, while shaping their identity and empowering them to build resilient communities. We believe that the key to social progress in Hungary is the creation of a strong Romani intelligentsia. Romaversitas works with Romani students from all over Hungary to help them overcome the disadvantages caused by systemic racism and allow them to meet their true potential". ${ }^{11}$

After the proliferation of Anti-Gypsyism, hate speech and hate crimes against the Roma, the perspective of 'paying back' has re-gained significance among next generation of Roma intellectuals and has re-appeared as guidance in local/social responsibility as a prerequisite for becoming a 'Roma intellectual' (Boros 2019). However, the vision of many of the Roma support programs of creating a Roma Intelligentsia implicates an indirect hidden cost for those former beneficiaries who had chosen a general (not racially directed) career path. Some of our 'assimilated' 
Roma interviewees are a case in point when they speak about their struggle with a feeling of divided loyalty and guilt. Dora is one whose story illustrates this concern.

Dora is a history teacher in a Western European country, in her early 40s. She is married to a migrant husband of another racialised minority background, with a child. Coming from a socio-economically disadvantaged, poor Roma family from a small village in Southern Hungary, she was recruited as a gifted Roma student by the Gandhi secondary school. After graduation from university, she moved abroad and settled down as a history teacher in a local high school. She loves teaching and she thinks of her work as a 'vocation'. In her narrative she recalled in what sense Roma support programs, especially Gandhi gymnasium, has helped her:

"Gandhi helped me in everything. It raised me from everything. If there is no Gandhi, I would be nowhere. I did my A-levels, I learnt English there. It gave me life; I learnt a lot about the world. I would have never learnt anything exciting at home. My mom had 6 years of schooling. Oh my God, what would I have turned out to be if I would have stayed at home? I would have had six children by now".

"Dora was one of very few interviewees who did not experience discrimination due to her 'light skin colour'. "Because of my skin colour, they accepted me everywhere as Hungarian. Had I been a bit darker, this program would have helped me with my identity formation. It immensely helped my other friends of darker sin".

Dora reflects that her Roma identity has lost its significance in her life since she lives abroad:

\footnotetext{
"Back then, at secondary school, life was all about that. Being a Roma. Today it is different. If I listen to good Gypsy music, I feel good. But it feels like I'm getting assimilated. Once you spend a lot of time in a non-Roma majority environment, you become similar to them, don't you? It makes me feel guilty sometimes. I don't know. I suppose I should keep more of my Gypsyness. I need to give something back to the Gypsy community. It's because I have had so much help from life due to being a Gypsy girl."
}

Similar to Dora, even those of our respondents who stayed and worked in Hungary and 'kept their Gypsyness' feel that this responsibility for and solidarity towards their community of origin is indirectly expected from them by the Roma intellectuals and by Roma support programs. Therefore, those few, who do not want to live up to this expectation and choose a general (not racially directed) career path, try to avoid these support programs, or choose only those that give scholarships and a non-Roma mentoring environment. Jennifer (a 24-year-old, MA student, studying 
International Relations) articulates the feeling some of our participants express about carrying a 'psychological burden':

"At home there was not much talk about us being Gypsy [cigány]. If I was to go to a Gypsy community, I feel that I am not Gypsy enough for them. I feel I'm inbetween the Hungarians and the Gypsies".

Although Jennifer was connected to a Roma talent program by her local Gypsy government while she was at primary school, and she is grateful to the program for its mentoring and bursary assistance, she did not want to join any Roma Student College. It is because she did not feel a strong belonging to the Roma community and was aware of the 'emotional burden' that these support programs put on the shoulders of their Roma students.

"This is a very difficult question for me. On the one hand, it is an honour that I can serve as an example to other Roma children and that I can help them. On the other hand, this is a burden. Isn't it enough that I struggled a lot and made it rise? Can I not enjoy a good life? I feel no, it's not the case, because in the subtext of these programs and of the Roma intelligentsia, there is this hidden expectation that if you break out [of poverty], you should deal with other Roma problems. I am my own master, I do what I like to do, I help who and when I like to help. I am grateful to the support program, but I feel I would have achieved what I did without it too. I have so much motivation to do well, I have had this inner drive and curiosity since I was a little kid."

\section{Conclusion}

Educational support and mentor programs contribute to the process of capital building among students coming from socio-economically disadvantaged family backgrounds where they lack many of the different types of capital that are necessary to accumulate in their social trajectory in order to get ahead and become successful in their careers and life. However, in Hungary, they seem to manage to reach out mostly to the upwardly mobile Roma. On the contrary, they rarely managed to support and address the problem of the 'price of mobility' for non-Roma first generation professionals coming from working class backgrounds.

Upwardly mobile, racialized minorities like the Roma in Hungary, have to face distinctive problems during their mobility journey (Neckerman et al. 1999). Unlike their non-racialized, white counterparts, they have to struggle with the persistent salience of discrimination in educational and everyday settings, along with responsibility (emotional burden) of interclass solidarity with co-ethnic members of one's community of origin, with those (mainly relatives) who are 'left behind'. Given the reason for this 
distinctive problem of upwardly mobile Roma professionals, the educational support programs that proved to be the most influential offer ethnically targeted and complex programs to foster education-driven upward mobility for the Roma.

These complex programmes play an important role in offering opportunities to acquire (white) middle class cultural capital to those mentees whose homes had not been able to secure it in the past. With their community building activities for likeminded peer mentees, and with cognitive and mental development services at hand, they also help heal the hidden injuries of class mobility (Skeggs 1997) for the firstin-family Roma graduates whose long-range upward mobility is unprecedented, and therefore sometimes distancing them in their family and community of origin.

These programs are also beneficial to mobility through providing scholarships to their mentees in order to help them overcome their constant financial difficulties. This financial capital has a huge symbolic value in their communities of origin, as it gives a message that it's worth studying even in a material sense. On top of that, support programs empower upwardly mobile Roma students with navigational capital to overcome structural barriers that underrepresented minority students face in a higher education environment. They also provide them with a place to meet with like-minded Roma peers, creating close friendships and dense ethnic networks and thus, a feeling of belonging and emotional shelter (Lukács-Dávid 2018, Nyírő-Durst 2018). Ethnically targeted support programs also enable mentees to recast negative and stigmatised identities through creating ethnic pride (see also Neményi-Vajda 2015) and a proud Roma middle class or Roma Intelligentsia identity (Kende 2007).

Considering all these academic support systems, in this paper we argue that one of the main contributions of the Roma educational support programs pertaining to the social mobility of the Roma is that they have been creating Roma cultural capital for their mentees. In our interpretation, Roma cultural capital is similar to Black cultural capital (Wallace 2016) in the sense that it is a set of resources that middleclass Roma youth can deploy to make meaning of their Roma identities, recast it, to forge networks of belonging and counter their marginal status, given Hungary's racialized power relations. Through this, Roma educational support programs that offer a complex approach, contribute hugely to mitigate the price of their upward mobility. According to the narratives of our study participants, they achieve this through reducing the psychological and emotional cost of changing class but remaining Roma, although their Roma (intellectual or middle class) identity differs from their low educated counterparts in their background communities. We showcased the example of Romaversitas to illustrate our argument.

However, the vision of many of the Roma support programs to create a Roma Intelligentsia implicates an indirect hidden cost for those former beneficiaries who had chosen a general (not racially directed) career path. Some of our 'assimilated' Roma interviewees are a case in point when they speak about their struggle with a feeling of guilt for not 'giving back' to their communities of origin. 


\section{References}

Abrahams, J. - Ingram, N. - Thatcher, J. - Burke, C. (2016): Conclusion: Bourdieu - The next generation. In Thatcher, J. - Ingram, N. - Burke, C. - Abrahams, J. (eds): Bourdieu: The Next Generation. The development of Bourdieu's intellectual heritage in contemporary UK sociology. Sociological Futures. London and New York:Routledge,157-166.

Arnold, P. - Ágyas, R. - Héra, G. - Katona, I. - Kiss, J. - Mészáros, Z. - Péter, J. - Pletser, A. - Rácz, A. - Rostás, G. - Szépe, A. (2011). Evaluation Research of Romaversitas Hungary Final Study.

Bereményi, Á. - Carrasco, S. (2017): Bittersweet Success: The Impact of Academic Achievement among the Spanish Roma After a Decade of Roma Inclusion. In: Pink, W. T. and Noblit, G. W. (eds.) Second International Handbook of Urban Education. New York: Spinger: 1169-1198 https://doi.org/10.1007/978-3-319-40317-5_62

Bereményi, Á. - Girós-Calpe, R. (2021): 'The more successful, the more apolitical'. Romani mentors' mixed experiences with an intra-ethnic mentoring project. British Journal of Education. https://doi.org/10.1080/01425692.2021.1941765

Bernát, A. (2014): Leszakadóban: a romák társadalmi helyzete a mai Magyarországon. Társadalmi riport 1: 246-267.

Bourdieu, P. (1984): Distinction. Cambridge, MA: Harvard University Press.

Bourdieu, P. (1986): The form of capital. In J.G. Richardson (ed.): Handbook of theory and research of the Sociology of education. New York: Greenwood Press, 241-258.

Bourdieu, P. (1996): The State Nobility. Stanford, CA: Stanford University Press. Bourdieu, P. (2016): 'Habitus'. In Hillier, J.- Rooksby (eds): Habitus: A Sense of Place. 27-34. Burlington, VT Ashgate. https://doi.org/10.4324/9781315253701

Bourdieu, P. (2008): Sketch for a Self-Analysis. London: Polity.

Boros, J. (2019): Cigány, roma fiatalok életútja: egy iskolán kívüli esélynövelö tanodatípusú program tagjainak vizsgálata. PhD thesis. University of Pécs. Doctoral School of Education.

Brüggemann, C. (2014): Romani Culture and Academic Success: Arguments Against the Belief in a Contradiction. Intercultural Education, 25(6): 439-452.

https://doi.org/10.1080/14675986.2014.990229

Carter, P. (2003): 'Black' Cultural Capital, Status Positioning, and Schooling Conflicts for Low-Income African American Youth. Social Problems, 50(1): 136-155. https://doi.org/10.1525/sp.2003.50.1.136

Dezső, A. R. (2011): „Minek nektek gimnázium?!” Középfokú cigány nemzetiségi oktatás Magyarországon 1989-2009: eredmények és kihivások, Ph.D. értekezés

Dezső, A. R. (2013): An Educational Experiment. The Case of the First Romani/ Gypsy Nationality Secondary School. PedActa. 3(1): 51-62.

Di Angelo, R. (2011): White Fragility. International Journal of Critical Pedagogy. 3(3): 54-70. 
DuBois, D.I. - Portillo, N. - Rhodes, J.E. - Silverthon, N. - Valentine, J.C. (2011): "How Effective Are Mentoring Programs for Youth? A Systematic Assessment of the Evidence." Psychological Science in the Public Interest: A Journal of the American Psychological Society, 12(2): 57-91. https://doi.org/10.1177/1529100611414806

Durst, J. - Bereményi,Á. (2021): "IFeltIArrived Home”: The Minority Trajectory of Mobility for First-in-Family Hungarian Roma Graduates. Social and Economic Vulnerability of Roma People, 229-250. https://doi.org/10.1007/978-3-030-52588-0_14

Fehérvári, A. - Varga, A. (eds.) (2018) : Reziliencia és inklúzió az Arany János Programokban.PécsiTudományegyetemBTKNTIRomológiaés Nevelésszociológiai Tanszék - Wlislocki Henrik Szakkollégium: Pécs

Forray, R. K. (2015): Életutak a felsőoktatásban. Romológia folyóirat, (3)10

Forray, R.K. (2017): A cigányság középosztályosodása. Educatio, 26(4): 581-590. https://doi.org/10.1556/2063.26.2017.4.6

Forray, R. K. - Pálmainé Orsós, A. (2010): Hátrányos helyzetû vagy kulturális kisebbség - cigány programok, Educatio, 1: 75-87.

Friedman, S. (2014): The price of the ticket: Rethinking the experience of social mobility. Sociology, 48(2), 352-368. https://doi.org/10.1177/0038038513490355

Friedman, S. (2016): The limits of capital gains: using Bourdieu to understand social mobility into elite occupations. In: Thatcher, J.-Ingram, N.-Burke, C.-Abrahams, J. (eds): Bourdieu: The Next Generation. The development of Bourdieu's intellectual heritage in contemporary UK sociology. Sociological Futures. London and New York: Routledge: 107-122. https://doi.org/10.4324/9781315693415-8

Friedman, S. - Laurison, D. (2020): The Class Ceiling. Why it Pays to be Privileged. Policy Press.

Garaz, S. - Torotcoi, S. (2017): Increasing Access to Higher Education and the Reproduction of Social Inequalities: The Case of Roma University Students in Eastern and Southeastern Europe. European Education, 49: 10-35. https://doi.org /10.1080/10564934.2017.1280334

Havas, G. - Liskó, I. (2006): Óvodától a szakmáig. Felsőoktatási Kutatóintézet, Új Mandátum Kiadó, Budapest.

Havas, G. (ed.) (2007). Utak a felsőoktatásba. Roma mobilitási pályák és a támogató intézmények. Kutatási beszámoló. Erasmus Kollégium Egyesület.

Hajdú, T. - Kertesi, G. - Kézdi, G. (2014): Roma fiatalok a középiskolában. Beszámoló a Tárki Életpálya-felvételének 2006 és 2012 közötti hullámaiból. Budapesti Munkagazdaságtani Füzetek Magyar Tudományos Akadémia Közgazdaság-és Regionális Tudományi Kutatóközpont Közgazdaságtudományi Intézet Budapesti Corvinus Egyetem, Emberi Erőforrás Tanszék BWP 7.

Halász, G. - Lannert, J. (eds.) (2006): Jelentés a magyar közoktatásról. Országos Intézet, Budapest

Havas, G. - Kemény, I. - Liskó, I. (2002): Cigány gyerekek az általános iskolában. Oktatáskutató Intézet, Új Mandátum Kiadó, Budapest. 
Ingram, N. - Abrahams, J. (2016): Stepping outside of oneself: how a cleft-habitus can lead to greater reflexivity through occupying 'the third space'? In Thatcher, J. - Ingram, N. - Burke, C. - Abrahams, J. (eds): Bourdieu: The Next Generation. The development of Bourdieu's intellectual heritage in contemporary UK sociology. Sociological Futures. London and New York:Routledge, 140- 156.

Kemény, I. - Janky, B. - Lengyel, G. (2004): A magyarországi cigányság 1971-2003. Gondolat Kiadó-MTA Etnikai-Nemzeti Kisebbségkutató Intézet 5-192.

Kende, A. (2007): 'Success Stories? Roma University Students Overcoming Social Exclusion in Hungary'. In H. Colley (ed): Social Inclusion for Young People: Breaking Down the Barriers. Strasbourg: Council of Europe, 133-144.

Keresztény Roma Szakkollégiumi Hálózat Alapító Okirata 'Founding Document Christian Roma College Network' http://krszh.hu/

Kertesi, G. - Kézdi, G. (2016): A roma fiatalokesélyei és az iskolarendszer egyenlőtlensége. Magyar Tudományos Akadéma Közgazdaság- és regionális Tudományi Kutatóközpont Közgazdaságtudományi Intézet, Budapest. 2-16.

Kóczé, A. (2020): Racialization, Racial Oppression of Roma. In: Ness, I. - Cope, Z. (eds): The Palgrave Encyclopedia of Imperialism and Anti-Imperialism. Palgrave Macmillan https://doi.org/10.1007/978-3-319-91206-6_124-1

Kovács, É. - Gárdos, J. - Vajda, R. (2020): Önszociológiák? Új kihívások a kvalitatív módszereket alkalmazó kutatásokban és archiválásukban. In Kultúra, közösség és társadalom: Tanulmányok Tibori Timea tiszteletére. Társadalomtudományi Kutatóközpont, Magyar Szociológiai Társaság, Budapest, 123-140.

Máté, D. (2021): Reziliens Romák a felsôoktatásban. PhD értekezés. Budapest: ELTE Doktori Iskola

Nyírő, Zs. - Durst, J. (2021): Racialisation rules: The effect of educational upward mobility on habitus. Szociológiai Szemle, 31(3), 21-50. https://doi.org/10.51624/ SzocSzemle.2021.3.2

Lannert, J. - Németh, Sz. - Szécsi J. (2018): Szegregáló deszegráció? In: Én vétkem: helyzetkép az oktatási szegregációról. 285-300.

Lareau, A. (2011): Unequal childhoods: Class, race and family life (2nd edition). Berkeley, CA: University of Californai Press.

Ligeti, Gy. (2001): Hátrányos helyzetűek az egyetemen. Esély, 6, 82-88

Lukács, J. - Dávid, B. (2018): Roma undergraduates' personal network in the process of college transition. A social capital approach. Research in Higher Education, 60(1), 64-82. https://doi.org/10.1007/s11162-018-9503-5

Luthans, F. - Avey, J.B. - Avolio, B.J. - Peterson, S. J. (2010): The development and resulting performance impact of positive psychological capital. Human resource development quarterly, 21(1): 41-67. https://doi.org/10.1002/hrdq.20034

Mallman, M. (2018): Disruption in the working-class family: the early origins of social mobility and habitus clive. In: Lawler, S. - Payne, G. (eds): Social Mobility 
for the 21st Century. Everyone a Winner? London and New York: Routledge: 25-36. https://doi.org/10.4324/9781351996808-3

Messing, V. - Molnár, E. (2008): „...több odafigyelés kellett volna”. A roma gyerekek iskolai sikerességének korlátairól. Esély, 4, 77-93.

Mirga, A. - Redzepi, N. (2020): Explaining the Educational Gap of Roma in Higher Education. In: Morley, L.- Mirga, A.- Redzepi, N. (eds): The Roma in European Higher Education. Recasting Identities, Re-Imagining Futures. London-New York: Bloomsbury Academic, 33-56. https://doi.org/10.5040/9781350109667.0007

Morley, L. (2014): 'Lost Leaders: Women in the Global Academy. Higher Education Research \& Development, 33(1): 114-128.

https://doi.org/10.1080/07294360.2013.864611

Morley, N. (2020): Roma as Knowledge Producers. In: Mirga, A. - Redzepi, N. (2020): The Roma in European Higher Education: Explaining the Educational Gap of Roma in Higher Education. In: Morley, L. - Mirga, A. - Redzepi, N. (eds): The Roma in European Higher Education. Recasting identities, Re-Imagining Futures. London - New York: Bloomsbury Academic

Naudet, J. (2018): Stepping into the elite. Trajectories of social achievement in India, France and the United States. Oxford: Oxford University Press.

Neckerman, K. - Carter, P. - Lee, J. (1999): Segmented assimilation and minority cultures of mobility. Ethnic and Racial Studies, 22(6), 945-965. https://doi. org/10.1080/014198799329198

Neményi, M. - Vajda, R. (2014): Intricacies of Ethnicity: A Comparative Study of Minority Identity Formation during Adolescence. In Szalai, J. - Schiff, C. (eds.): Migrant, Roma and Post-Colonial Youth in Education across Europe. Being 'Visibly' Different. Palgrave Macmillan, 103-119.

Németh, K. (2015): A terepmunka és a kutatói pozíció reflektálása mint az értelmezés rejtett erőforrása. In: Virág, T. (szerk.): Törésvonalak. Budapest: Gondolat Kiadó

Nyírő, Zs. - Durst, J. (2018): Soul Work and Giving Back: Ethnic Support Groups and the Hidden Costs of Social Mobility. Lessons form Hungarian Roma Graduates. INTERSECTIONS: East European Journal of Society and Politics, 4(1): 88-108.

Nyírő, Zs. (2021): The effect of educational mobility on habitus. Budapest: Corvinus University, Doctoral School of Sociology.

OECD (2018): Education at a glance. 2018 OECD Indicator. Paris: OECD Publications Óhidy, A. (2016): A 'roma közösségi kulturális tőke' szerepe roma és cigány nők sikeres iskolai pályafutásában - Egy kvalitatív kutatás eredményei. Magyar Pedagógia. 116 (2): 171- 196. https://doi.org/10.17670/MPed.2016.2.171

Óhidy, A. - Comes, N. - Pikula, N. (2020): Mentoring programmes for disadvantaged children in selected European countries. Hungarian Education Research Journal, 10(3): 180-188. https://doi.org/10.1556/063.2020.00019

Orsós, A. (2015): A beás nyelv. In: A romológia alapjai, Pécsi Tudományegyetem BTK NTI Romológia és Nevelésszociológia Tanszék - WHSZ, Pécs. 151-181. 
Pantea, M. C. (2015): Affirmative action in Romania's higher education: Roma students' perceived meanings and dilemmas. British Journal of Sociology of Education, 36(6): 896-914. https://doi.org/10.1080/01425692.2013.869172

Papp, Z. A. (2011): A roma tanulók aránya Magyarországon és a tanulói teljesítmények az általános iskolában. In: Bárdi, N. - Tóth, Á. (szerk.): Asszimiláció, integráció, szegregáció: Párhuzamos értelmezések és modellek a kisebbségkutatásban. Budapest: Argumentum, 224-267.

Papp, Z. A. - Neumann, E. (2021). Education of Roma and Educational Resilience in Hungary. In Mendes, M. M. - Magano, O. - Toma, S. (eds.): Social and Economic Vulnerability of Roma People: Key Factors for the Success and Contiunity of Schooling Levels. New York: Springer, 79-95.

Radó, P. (2018): A közoktatás szelektivitása mint a roma szegregáció általános kontextusa. In Fejes, B.- Szűcs, N. (eds): Én vétkem. Helyzetkép az oktatási szegregációról. Szeged: Motiváció Oktatási Egyesület, 31-56.

Reay, D. (2005): Beyond consciousness? The psychic landscape of social class. Sociology. 39 (5): 911-928. https://doi.org/10.1177/0038038505058372

Skeggs, B. (1997): Formations of Class and Gender. Becoming Respectable. London: SAGE. Sorokin, P. A. (1959): Social and cultural mobility. Free Press.

Stanton-Salazar, R.D. (2004). Social capital among working-class minority students. In M. A. Gibson, P. Gándara - J. Peterson Koyama (Eds.): School connections. U.S. Mexican youth, peers, and school achievement. New York: Teachers College, Columbia University.

Thatcher, J. - Halvorsrud, K. (2016): Migrating habitus: a comparative case study of Polish and South African migrants in the UK. In: Thatcher, J.-Ingram, N.Burke, C.- Abrahams, J. (eds): Bourdieu: The Next Generation. The development of Bourdieu's intellectual heritage in contemporary UK sociology. Sociological Futures. London and New York: Routledge: 88-106.

Varga, A. (2016): A hazai oktatási integráció tapasztalatok és lehetôségek. Neveléstudomány, Oktatás, Kutatás, Innováció: 1 71-91.

Varga, A. (2018): A rendszerváltás gyermekei: Cigány/roma fiatalok életútja egy húsz évet felölelő kutatás tükrében. PTE BTK Neveléstudományi Intézet, Romológia és Nevelésszociológia Tanszék, Wislocki Henrik Szakkollégium, 219.

Varga, A. - Trendl, F. - Vitéz, K. (2020): Development of positive psychological capital at a Roma Student College. Hungarian Education Research Journal, 10: 263279. https://doi.org/10.1556/063.2020.00024

Váradi, M. (2015): Roma nők a projektvilágban: portrék. In Virág T. (ed.): Törésvonalak. Szegénység és etnicitás vidéki terekben. Budapest: Argumentum, 121-140.

Wallace, D. (2016): Re-interpreting Bourdieu, belonging and Black identities: exploring 'Black' cultural capital among Black Caribbean youth in London. In: Thatcher, J. - Ingram, N. - Burke, C. - Abrahams, J. (eds): Bourdieu: The Next 
Generation. The development of Bourdieu's intellectual heritage in contemporary UK sociology. Sociological Futures. London and New York: Routledge: 37-54. https://doi.org/10.4324/9781315693415-4

Wallace, D. (2018): Cultural capital as whiteness? Examining logics of ethno-racial represeantation and resistance. British Journal of Sociology and Education, 39(4), 466-482. https://doi.org/10.1080/01425692.2017.1355228

Yosso, T. J. (2005): Whose Culture Has Capital? A Critical Race Theory Discussion of Community Cultural Wealth. Race, Ethnicity and Education, 8(1), 69-91. https://doi.org/10.1080/1361332052000341006 